\title{
Modifikasi Desain dan Metode Pelaksanaan Duplikasi Jembatan Sembayat Kabupaten Gresik pada STA 0+350 - STA 0+530 dengan Sistem Jembatan Busur Rangka Baja
}

\author{
R. B. A. Affandhie ${ }^{1, *}$, Chomaedhi ${ }^{1}$, E. Hardiyanto ${ }^{1}$ \\ Departemen Teknik Infrastruktur Sipil, ITS, Surabaya ${ }^{1}$ \\ Koresponden*, Email: rba.affandhie@gmail.com
}

\begin{tabular}{|c|c|}
\hline Info Artikel & Abstract \\
\hline $\begin{array}{l}\text { Diajukan } 31 \text { Agustus } 2017 \\
\text { Diperbaiki 04 Desember } 2017 \\
\text { Disetujui } 28 \text { Pebruari } 2018\end{array}$ & $\begin{array}{l}\text { To increase the capacity of Sembayat bridge, it is planned to build duplication of Sembayat } \\
\text { bridge with 353,445 meters span length by using steel trussed bridge structure. The existing } \\
\text { structure system of Sembayat bridge duplication is not suitable for long span bridges, } \\
\text { because the addition of the subsstrcture construction. In this paper will be submitted the } \\
\text { modified of Sembayat bridge duplication design, the bridge span is planned } 180 \text { m length } \\
\text { with } 15 \text { m width. The structure system is arc with a half-through type. The steel trussed arch } \\
\text { has ability to sustain structures and notably has better aesthetic than another type. In this } \\
\text { design, the calculated based on SNI 1725: 2016, RSNI T-03-2005, RSNI T-12-2004, RSNI }\end{array}$ \\
\hline $\begin{array}{l}\text { Keywords: arch bridge, steel } \\
\text { trussed, } \quad \text { Sembayat bridge, } \\
\text { balanced cantilever. }\end{array}$ & $\begin{array}{l}2833-2016 \text { and AISC } 2010 \text {. From the analysis, the main profile of lower chords was } \\
\text { designed using steel box } 1100.900 .50 \text { and } 900.700 .50 \text { for upper chords. Balanced cantilever } \\
\text { was planned as the construction method of Sembayat bridge. }\end{array}$ \\
\hline
\end{tabular}

\begin{abstract}
Abstrak
Untuk meningkatkan kapasitas Jembatan Sembayat, direncanakan pembangunan duplikasi Jembatan Sembayat dengan panjang bentang 353,445 meter menggunakan struktur jembatan rangka baja. Sistem struktur pada duplikasi Jembatan Sembayat tersebut tidak sesuai untuk jembatan tipe bentang panjang, karena berpengaruh pada penambahan konstruksi pilar jembatan. Pada tulisan ini disampaikan modifikasi perencanaan duplikasi Jembatan Sembayat, bentang jembatan direncanakan memiliki panjang total $180 \mathrm{~m}$ dengan lebar $15 \mathrm{~m}$. Sistem struktur yang digunakan adalah sistem busur dengan rangka batang tipe half-through. Struktur busur rangka memiliki kemampuan untuk menopang struktur dengan bentang yang panjang dan memiliki nilai estetika lebih baik. Perencanaan struktur bangunan atas dan bawah jembatan dihitung berdasarkan peraturan jembatan yang berlaku, antara lain SNI 1725:2016, RSNI T-032005, RSNI T-12-2004, RSNI 2833-2016 dan AISC 2010. Dari hasil analisa didapat profil utama busur bawah menggunakan profil box 1100.900.50 dan busur atas menggunakan profil 900.700.50. Metode pelaksanaan pembangunan duplikasi Jembatan Sembayat direncanakan menggunakan Metode Balanced Cantilever.
\end{abstract}

Kata kunci: jembatan busur, rangka batang, Jembatan Sembayat, balanced cantilever. menarik dari segi estetikanya, penulis melakukan modifikasi desain duplikasi Jembatan Sembayat dengan tipe jembatan busur (half-trough arch bridge).

Kondisi topografi lokasi pembangunan jembatan merupakan bantaran sungai yang memiliki lereng cukup curam dengan dasar sungai berada di elevasi $-13 \mathrm{~m}$ dan tinggi bebas $-8 \mathrm{~m}$ dari permukaan jalan. Penggunaan jembatan tipe rangka baja sebagaimana pada jembatan eksisiting dengan bentang panjang dinilai tidak sesuai karena harus menggunakan konstruksi pilar di tengah alur sungai. Berdasarkan kondisi Jembatan Sembayat eksisting tersebut, maka pada perencanaan duplikasi Jembatan Sembayat ini dilakukan modifikasi desain jembatan dengan menggunakan tipe half-trough arch bridge, karena pada tipe ini memiliki 
beberapa kelebihan antara lain bentuk struktur yang ada dapat melawan momen lentur yang terjadi, bentuknya mempunyai nilai estetika yang cukup tinggi serta dapat mengurangi jumlah pilar yang ada di tengah alur sungai. Dilihat dari kondisi topografi Jembatan Sembayat eksisting, idealnya jembatan yang ada menggunakan jembatan busur dengan sistem rangka batang.

Perencanaan duplikasi Jembatan Sembayat ini menggunakan rangka busur baja dengan 1 bentang yang terdiri dari 4 lajur dan 2 arah (4/2 UD) pada STA 0+350 - STA 0+530. Lebar pada tiap lajurnya direncanakan $3.00 \mathrm{~m}$ ditambah dengan lebar trotoar di kanan dan kiri masing-masing 1,50 m, sehingga total lebar jembatan selebar 15 meter dengan panjang bentang 180 meter.

Dalam penulisan ini akan disampaikan perhitungan struktur bangunan atas jembatan busur (half trough arch bridge) rangka baja, dimana pada struktur baja jembatan ini digunakan penampang rangka yang memiliki nilai lebih pada kemampuan lentur dan kemudahan pelaksanaannya. Untuk struktur bangunan bawah menggunakan struktur beton dengan pondasi tiang pancang. Pembuatan struktur rangka baja bisa dilakukan terlebih dahulu melalui proses pabrikasi yang selanjutnya dipasang (erection) di lapangan dengan menggunakan metode balanced cantilever.

Mengingat permasalahan yang cukup luas, maka perlu adanya pembatasan masalah sebagai berikut:

1. Perencanaan struktur jembatan busur hanya dilakukan pada STA 0+350 - STA 0+530 sepanjang 180 meter.

2. Analisa struktur jembatan menggunakan metode Perencanaan Beban dan Kekuatan Terfaktor (PBKT) atau Load and Resistance Factor Design (LRFD)

3. Melakukan analisa plat lantai kendaraan, sistem rangka baja, sambungan yang dianggap mewakili secara keseluruhan, perletakan, pilar, abutment dan pondasi tiang pancang.

4. Perhitungan gaya dalam dan analisa struktur dilakukan dengan menggunakan software.

5. Metode pelaksanaan jembatan hanya disampaikan secara umum tanpa membahas detail setiap segmennya

\section{Metode}

Jembatan adalah suatu bangunan yang memungkinkan suatu jalan menyilang saluran air, lembah, atau menyilang jalan lainnya yang tidak sama tinggi permukaannya dan lalulintas jalan itu tidak terputus karenanya[1].

Jembatan sistem rangka adalah sistem struktur jembatan tersusun dari batang-batang profil yang dihubungkan satu sama lain. Batang-batang tersebut disusun sedemikian rupa sehingga akan terjadi gaya aksial tekan ataupun tarik[2].
Pada tahapan awal perencanaan jembatan dilakukan studi literatur. Tahapan kedua adalah pengumpulan data sekunder yang didapat dari Pemilik Pekerjaan, Dinas Pekerjaan Umum dan Perumahan Rakyat Kabupaten Gresik sebagai berikut:

$$
\begin{array}{ll}
\text { - Nama } & \text { : Jembatan Sembayat } \\
\text { - Lokasi } & : \text { Kabupaten Gresik } \\
\text { - Panjang } & : 353,445 \text { meter } \\
\text { - Lebar } & : 15 \text { meter }
\end{array}
$$

Perencanaan struktur bangunan atas dimulai dengan perencanaan plat lantai jembatan sebagai struktur komposit dengan gelagar melintang serta perencaanaan struktur utama busur yang menggunakan tipe half trhough arch (gambar 1).

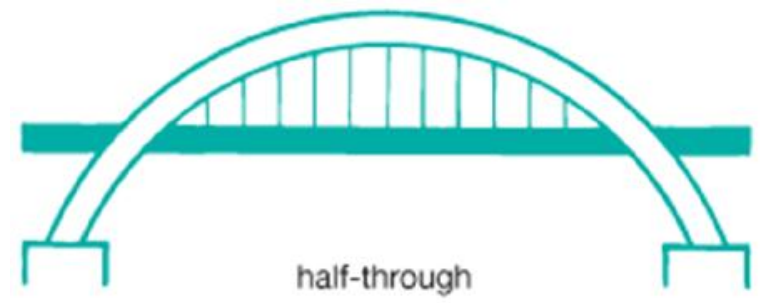

Gambar 1. Jembatan tipe half trhough arch Sumber: Soemargo [3]

Perencanaan struktur bangunan bawah yang disampaikan terdiri 1 struktur abutment dan 1 struktur pilar yang dianggap paling kritis yang ditunjang oleh pondasi tiang pancang. Standar acuan yang dipakai pada perencanaan bangunan atas adalah RSNI T-03-2005 [4], RSNI T-12-2004 [5], SNI 1725:2016 [6] yang digunakan dalam perhitungan tegangantegangan dalam konstruksi adalah beban primer, beban sekunder dan beban khusus.

1. Beban Mati

Beban mati terdiri dari dua jenis beban, yaitu:

a. Berat Sendiri (Self Weight Dead)

Berat bahan dan bagian jembatan yang merupakan elemen struktural ditambah dengan elemen non struktural yang dianggap tetap.

b. Beban mati tambahan (Superimposed Dead Load)

Beban Mati Tambahan adalah berat seluruh bahan, yang merupakan elemen non struktural serta merupakan beban pada jembatan berupa beban aspal dan beban air hujan.

2. Beban Hidup (Live Load)

Beban hidup dalam hal ini adalah beban lalu lintas. Beban lalu lintas untuk perencanaan jembatan terdiri dari beban "D" dan beban truk "T".

a. Beban lajur "D"

Beban lajur "D" terdiri dari beban terbagi rata Uniformly Distributed Load (UDL) yang digabung dengan beban garis Knife Edge Load (KEL) seperti pada gambar 2 [6]. 


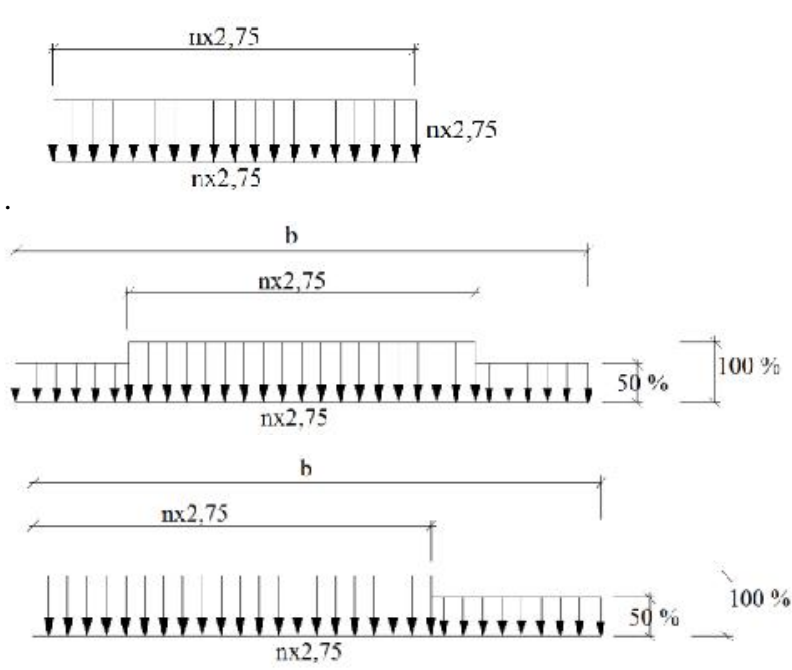

Gambar 2. Beban Lajur "D"

Sumber: SNI 1725:2016 [6]

b. Pembebanan Truk "T"

Pembebanan truk "T" terdiri dari kendaraan truk semi trailer yang mempunyai susunan dan berat as seperti yang terlihat pada gambar 3 [6].
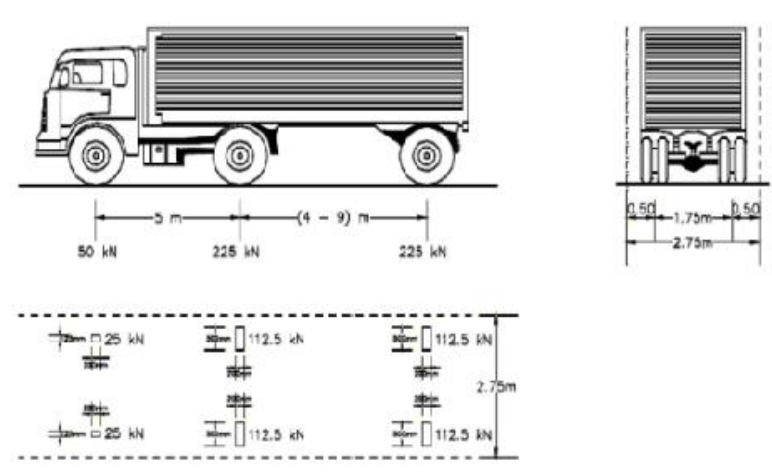

Gambar 3. Beban Truk "T"

Sumber: SNI 1725:2016 [6]

\section{Beban Kejut}

Faktor Beban Dinamis merupakan interaksi antara kendaraan yang bergerak dengan jembatan. Untuk bentang menerus panjang bentang ekuivalen LE diberikan pada rumus 1.[6]

$$
\mathrm{L}_{\mathrm{E}}=\overline{L_{E v}} \overline{L_{\max }}
$$

dengan:

Lev = panjang bentang rata-rata

Lmax $=$ panjang bentang maksimum

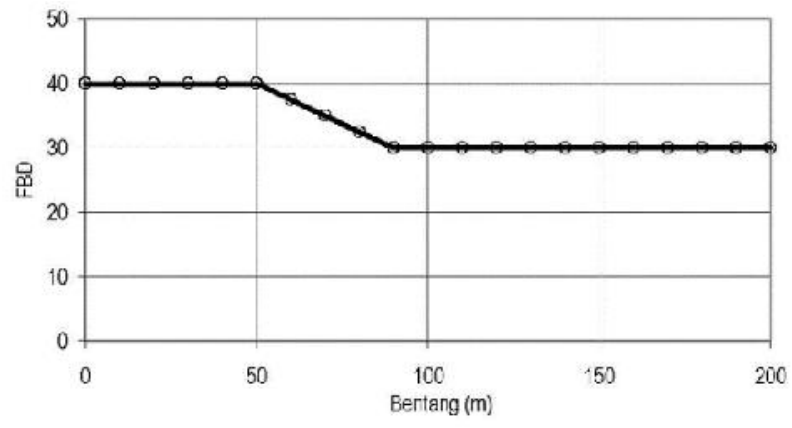

Gambar 4. Grafik Faktor Beban Dinamis untuk KEL pada Beban Lajur D

Sumber: SNI 1725:2016 [6]

\section{Beban Angin}

Gaya angin nominal ultimit pada jembatan tergantung pada kecepatan angin rencana dengan perumusan 2 dan 3. [6]

$\mathrm{T}_{\mathrm{ew}}=0,0006 C_{W}(V w)^{2} A b(\mathrm{kN})$

dengan :

$V w \quad=$ kecepatan angin rencana $(\mathrm{m} / \mathrm{det})$

$C w=$ koefisien seret

$A b=$ luas ekuivalen bagian samping jembatan $\left(\mathrm{m}^{2}\right)$

$\mathrm{T}_{\mathrm{ew}}=0,0012 \mathrm{C}_{\mathrm{W}}(\mathrm{Vw})^{2}(\mathrm{kN})$

dimana $C w=1,2$.

5. Gaya Rem

Pengaruh percepatan dan pengereman dari lalu lintas harus diperhitungkan sebagai gaya dalam arah memanjang dan dianggap bekerja pada permukaan lantai jembatan (gambar 5). [6]

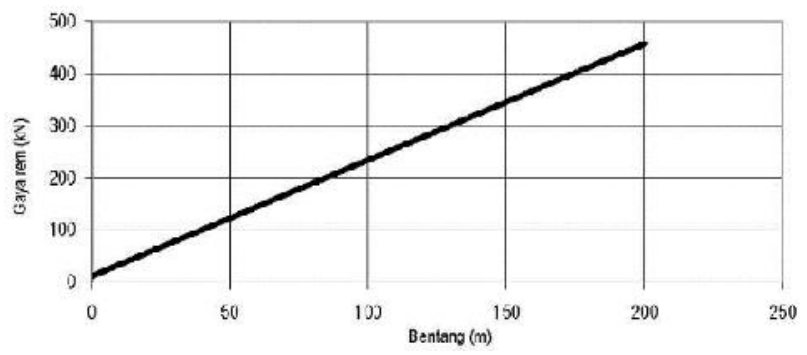

Gambar 5. Grafik Gaya Rem

Sumber: SNI 1725:2016 [6]

Pembebanan Bangunan Bawah:

1. Beban Akibat Kombinasi Pembebanan

Beban total keseluruhan struktur bangunan atas yang diterima oleh perletakan pada pilar dan abutment, didapatkan dengan menggunakan kombinasi pembebanan sesuai dengan pembebanan untuk jembatan [6]. 
2. Beban Gempa Horizontal Statis

Perhitungan beban gempa bangunan bawah Jembatan Sembayat ini diperoleh dari rumus 4 [7].

$E Q=\frac{C_{s m}}{R_{d}} x W t$

dengan:

$E Q \quad=$ Gaya Gempa Horizontal Statis $(\mathrm{kN})$

$C S M=$ Koefisien Respon Gempa Elastis

$R d \quad=$ Faktor Modifikasi Respon

$W t \quad=$ Berat Total Struktur

3. Beban Tekanan Tanah Aktif

Gaya yang diakibatkan oleh tekanan tanah dapat menimbulkan geser dan momen pada struktur bangunan bawah. Pada perencanaan ini, beban tekanan tanah aktif hanya diterima Nilai dari koefisien tanah dapat dicari menggunakan rumus 5 .

$K a=\tan ^{2} \quad 45-\frac{\phi}{2}$

dengan:

$K a \quad=$ Tekanan Tanah Aktif

$\phi \quad=$ Sudut Geser Tanah

Pada perencanaan Jembatan Sembayat ini digunakan pondasi dalam. Pondasi dalam sering juga dinamakan pondasi tak langsung, karena beban-beban yang terjadi akan diteruskan ke lapisan tanah yang mampu memikulnya. Letak dari lapisan tanah tersebut umumnya relatif dalam dari permukaan tanah setempat, sehingga beban yang terjadi terlebih dahulu harus disalurkan melewati suatu konstruksi penerus yang disebut pondasi tiang pancang.

\section{Hasil dan Pembahasan \\ Preliminary Design}

Perencanaan modifikasi duplikasi Jembatan Sembayat menggunakan konstruksi busur rangka baja dengan kedudukan lantai di tengah. Konstruksi jembatan juga menggunakan batang tarik yang berfungsi menahan beban lateral.

Data umum perencanaan modifikasi desain duplikasi jembatan Sembayat adalah sebagai berikut:

$\begin{array}{ll}\text { Panjang jembatan } & : 180 \text { meter } \\ \text { Tinggi fokus busur } & : 35 \text { meter } \\ \text { Lebar lantai kendaraan }(\lambda) & : 12 \text { meter (2 arah) } \\ \text { Lebar trotoar } & : 1,5 \text { meter } \\ \text { Tebal aspal (d2) } & : 4 \mathrm{~cm} \\ \text { Tebal plat lantai kendaraan (d1) } & : 25 \mathrm{~cm} \\ \text { Jarak gelagar melintang (b1) } & : 200 \mathrm{~cm}\end{array}$

Perbedaan potongan memanjang desain awal [8] dengan potongan memanjang rencana modifikasi desain ditunjukkan pada gambar 6 dan 7 .

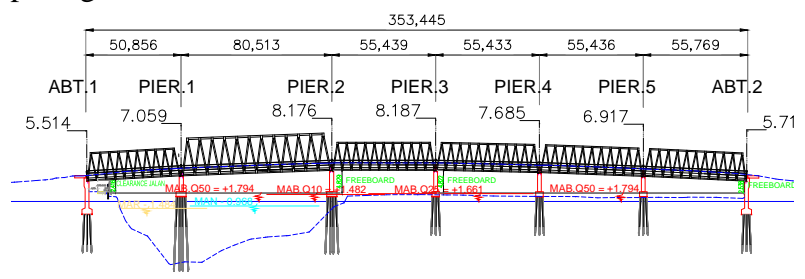

Gambar 6. Potongan Memanjang Desain Awal Sumber: Prasmoro [8]

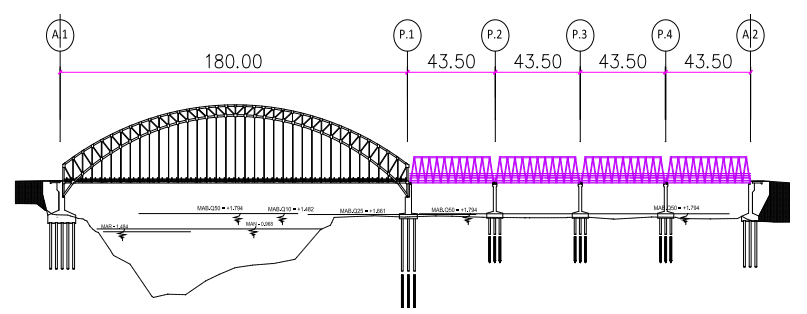

Gambar 7. Potongan Memanjang Rencana Modifikasi Desain

Sumber: Hasil Analisa

\section{Perencanaan Struktur Sekunder}

1. Tiang Sandaran dan Trotoar

Direncanakan tiang sandaran dengan dimensi $250 \times 250 \times 1500 \mathrm{~mm}$, dengan dimensi pipa $\varnothing 76,3 \mathrm{~mm}(3$ inchi) (gambar 8). Tulangan sandaran digunakan 2-D16 untuk tulangan lentur, dan $\varnothing 10$ - 100 untuk tulangan geser.

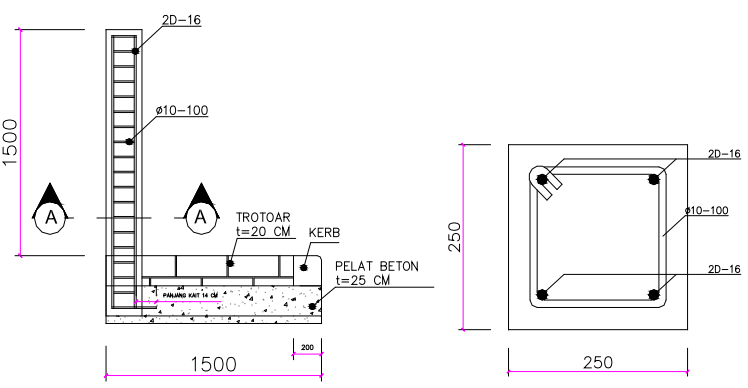

Gambar 8. Detail Tiang Sandaran

Sumber: Hasil Analisa

2. Plat Lantai Jembatan

Plat lantai jembatan merupakan struktur komposit antara beton bertulang dengan compodeck dengan perhitungan mengacu pada RSNI T-12-2004 [3]. Detail hasil perencanan plat lantai kendaraan sebagai berikut (gambar 9):
Tebal pelat
$=250 \mathrm{~mm}$
Tinggi compodeck$$
=51 \mathrm{~mm}
$$ 


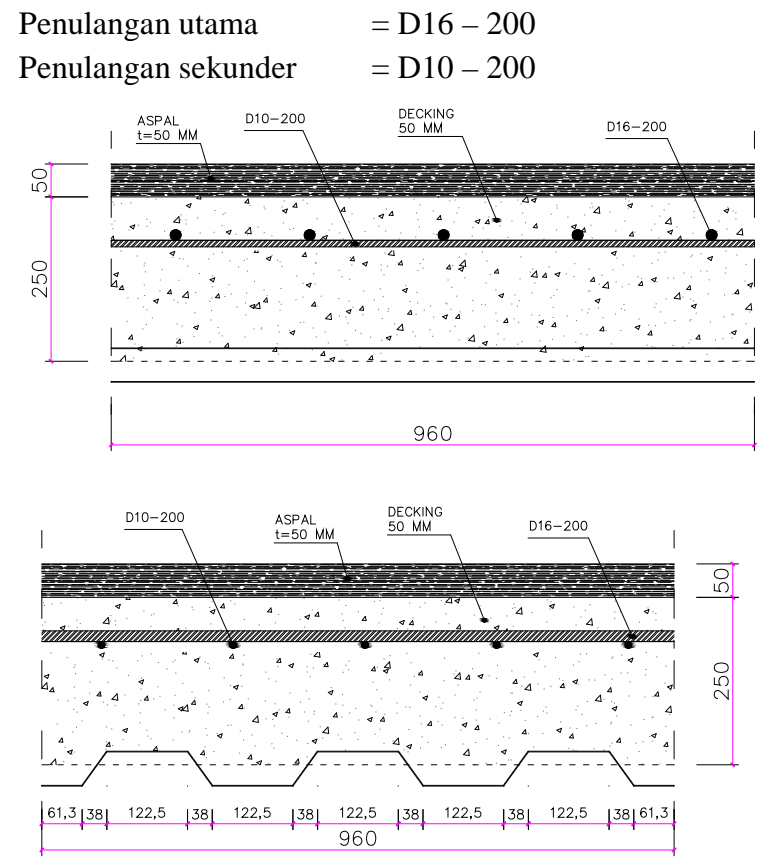

Gambar 9. Detail Plat Lantai Kendaraan Sumber: Hasil Analisa

\section{Perencanaan Gelagar (Girder)}

Pada perencanaan gelagar menggunakan profil baja WF dengan mutu baja BJ 55, dengan fy =410 MPa dan $\mathrm{fu}=550$ $\mathrm{MPa}$.

1. Gelagar Memanjang

Gelagar memanjang diasumsikan sebagai simple beam dan menggunakan profil WF 488.300.18.11. Distribusi pembebanan pada gelagar memanjang bisa dilihat pada gambar 10 dan tabel 1 .

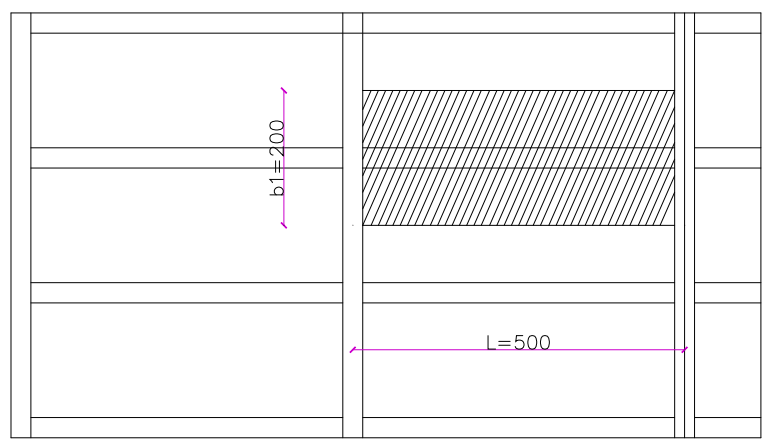

Gambar 10. Distribusi Pembebanan Pada Gelagar Memanjang

Sumber: Hasil Analisa
Tabel 1. Pembebanan Pada Gelagar Memanjang

$$
\text { Jenis Beban Beban Ultimite (N/m) }
$$

\begin{tabular}{cr}
\hline Berat Sendiri (MS) & \\
\hline Beban Plat Lantai & 14800.50 \\
Berat Sendiri Profil & 1411.85 \\
Beban Compodeck & 16.68 \\
\hline Berat Tambahan (MA) & 2860.00 \\
\hline Beban Aspal & 1000.00 \\
Beban Hujan & 8880.30 \\
Beban Trotoar & \\
\hline Beban "T" (kN) & 263.25 \\
\hline Beban Truk "T" & 21.00 \\
\hline Beban "D" (kN/m) & 127.40 \\
\hline Beban BTR & \\
Beban BGT & \\
\hline
\end{tabular}

Dari perhitungan pembebanan diatas didapat nilai gaya dalam maksimum sebagai berikut:

- $\mathrm{Mu}=545,81 \mathrm{kNm}$

- $\mathrm{Vu}=344,34 \mathrm{kN}$

Berdasarkan analisa kuat nominal lentur, gelagar memanjang merupakan bentang menengah karena dengan $\mathrm{Lp}<\mathrm{Lb}<\mathrm{Lr}$. Besarnya momen nominal yang terjadi dihitung seperti rumus 6 .

$$
\begin{aligned}
& \mathrm{Mn}=C b M r+(M p-M r) \frac{(L r-L b)}{(L r-L p)} \\
& \begin{aligned}
M n & =1,258989400+\left(1,27.10^{9}-989400\right) \frac{(6900,95-5000)}{(6900,95-2736,58)} \\
& =729,976 \mathrm{kNm}
\end{aligned}
\end{aligned}
$$

Kontrol momen ultimate dengan momen nominal penampang dilakukan sebagai berikut:

$\begin{array}{ll}\varnothing \mathrm{Mn}_{\text {aktual }} & \geq \mathrm{Mu} \\ 0,9 \times 729,976 \mathrm{kNm} & \geq 545,81 \mathrm{kNm} \\ 656,978 \mathrm{kNm} & \geq 545,81 \mathrm{kNm}\end{array}$

(Memenuhi)

Jadi, gelagar memanjang WF 4883001811 bisa digunakan.

\section{Gelagar Melintang}

Gelagar melintang juga diasumsikan sebagai simple beam dengan menggunakan profil WF 900.300.28.16. Distribusi pembebanan pada gelagar melintang dilakukan sebagaimana pada gambar 11. 


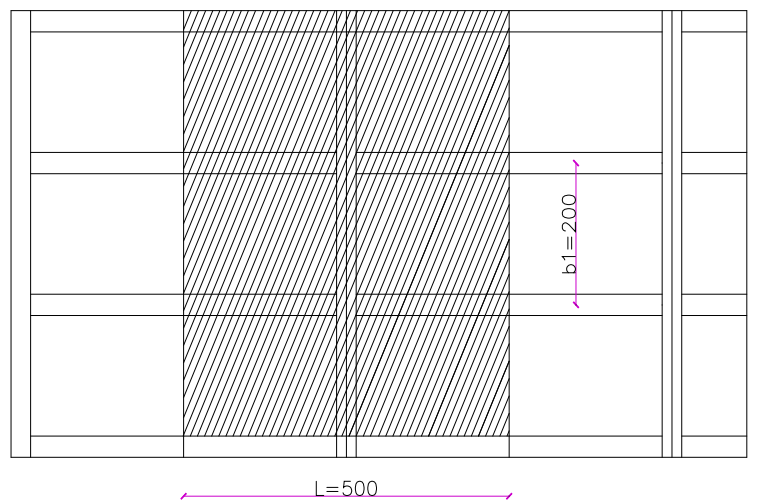

Gambar 11. Distribusi Pembebanan Pada Gelagar Melintang Sumber: Hasil Analisa

Pada perencanaan pembebanan gelagar melintang dianalisa dalam dua kondisi, yaitu sebelum komposit dan setelah komposit. Pembebanan pada gelagar melintang disajikan pada Tabel 2.

Tabel 2. Rekapitulasi Pembebanan Pada Gelagar Melintang

\begin{tabular}{lr}
\hline \multicolumn{1}{c}{ Jenis Beban } & $\begin{array}{c}\text { Beban Ultimite } \\
(\mathrm{N} / \mathrm{m})\end{array}$ \\
\hline Beban permanen sebelum komposit (MS) & \\
\hline Beban Plat Lantai & 37001.25 \\
Berat Sendiri Profil Melintang & 2675.09 \\
Beban Compodeck & 41.69 \\
Beban Bekisting & 5460.00 \\
\hline Beban permanen setelah komposit (MA) & \\
\hline Beban Aspal & 7150.00 \\
Beban Trotoar & 29601.00 \\
\hline Beban Lalu Lintas & 263250 \\
\hline Beban Truk "T" & 52500.00 \\
Beban BTR (100\%) & 127400.00 \\
\hline Beban BGT (100\%)
\end{tabular}

Analisa kapasitas penampang direncanakan setelah komposit yaitu setelah dipasang shear connector dengan distribusi tekan dan tarik bisa dilihat pada gambar 12 .

Hasil perhitungan diperoleh nilai kekutan tekan pada plat lantai kendaraan $(\mathrm{C})=7849842,857 \mathrm{~N}$, kekuatan tarik pada gelagar $(\mathrm{T})=12701800 \mathrm{~N}$ dan garis netral plastis $(\mathrm{a})=$ $175,192 \mathrm{~mm}$. Nilai momen nominal komposit adalah sebagai berikut:

$$
\begin{aligned}
\text { Ms } & =\mathrm{T} \times \mathrm{d} 1 \\
& =7849842,857 \mathrm{~N} \times 694 \mathrm{~mm} \\
= & 5447790,943 \mathrm{Nmm} \\
= & 5447,791 \mathrm{kNm}
\end{aligned}
$$

d1

$$
\begin{aligned}
& =\mathrm{hs} / 2+\mathrm{tp}-\mathrm{a} / 2 \\
= & (900) / 2+250-(175,192) / 2 \\
= & 612,404 \mathrm{~mm}
\end{aligned}
$$

Kontrol:

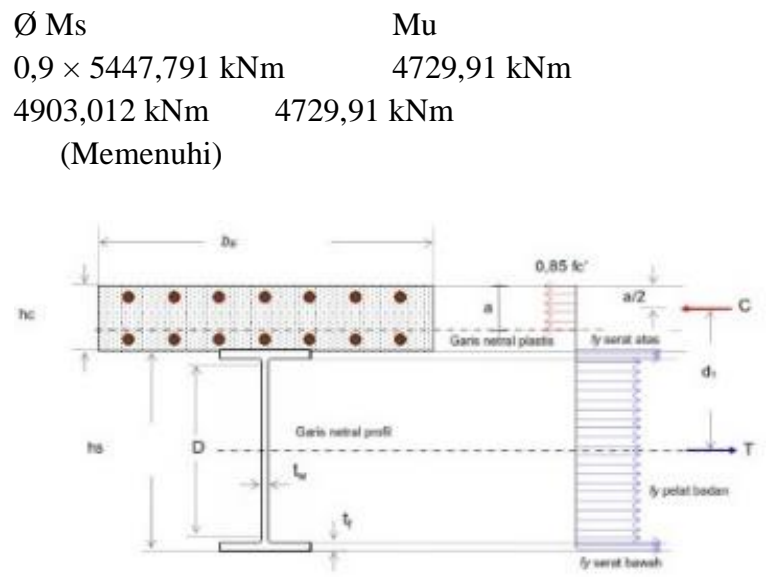

Gambar 12. Diagram Tegangan Plastis Sumber: Hasil Analisa

3. Perencanaan Komponen Busur

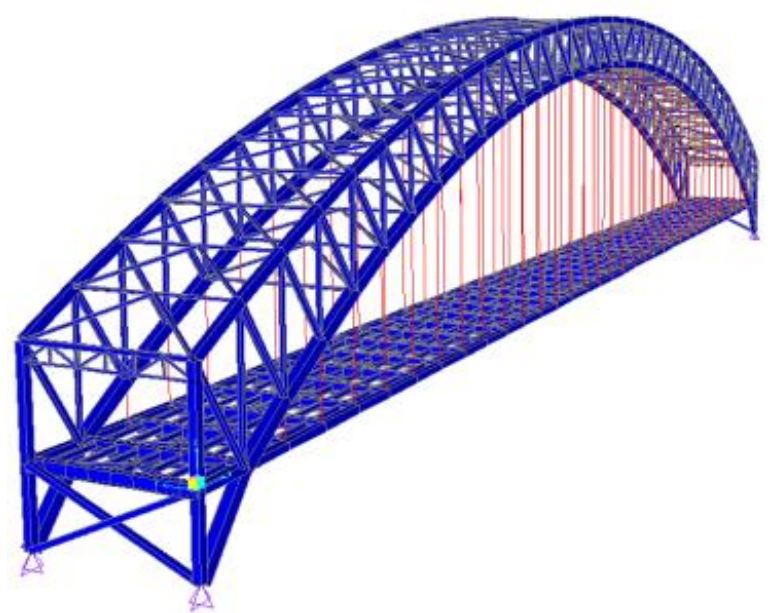

Gambar 13. Tampak Perspektif Jembatan Busur Rencana Sumber: Hasil Analisa

Keseluruhan bagian pelengkung menerima tekan, kemudian gaya tekan ini ditransfer ke abutment dan ditahan oleh tegangan tanah dibawah pelengkung. Tanpa gaya tarik yang diterima oleh pelengkung memungkinkan jembatan pelengkung bisa dibuat lebih panjang dari jembatan balok dan bisa menggunakan material yang tidak mampu menerima tarik dengan baik seperti beton.

Perencanaan struktur utama menggunakan sistem busur rangka baja ditambah dengan menggunakan material cable 
sebagai batang tarik. Pada perencanaan awal dimensi busur menggunakan rumus parabola.

Direncanakan tinggi busur (f) $=35 \mathrm{~m}$.

$$
\begin{aligned}
\mathrm{f} \quad & =\frac{1}{6} \leq f / L \leq \frac{1}{5} \\
& =0,17 \leq \frac{35}{180} \leq 0,2 \\
& =0,17 \leq 0,19 \leq 0,2 \\
& \text { (Memenuhi) }
\end{aligned}
$$

Direncanakan tinggi busur $(\mathrm{H})=6 \mathrm{~m}$.

$$
\begin{aligned}
\mathrm{H} \quad & =\frac{1}{40} \leq \frac{H}{L} \leq \frac{1}{25} \\
= & \frac{1}{40} \leq \frac{H}{L} \leq \frac{1}{25} \\
= & 0,025 \leq \frac{6}{180} \leq 0.04 \\
= & 0,025 \leq 0,033 \leq 0,04 \\
& \text { (Memenuhi) }
\end{aligned}
$$

\section{Permodelan Pembebanan}

Permodelan pembebanan dilakukan dengan bantuan software yang meliputi beban mati, beban lalu lintas dan beban aksi lingkungan sesuai dengan peraturan SNI 1725:2016.[6]

1. Beban mati

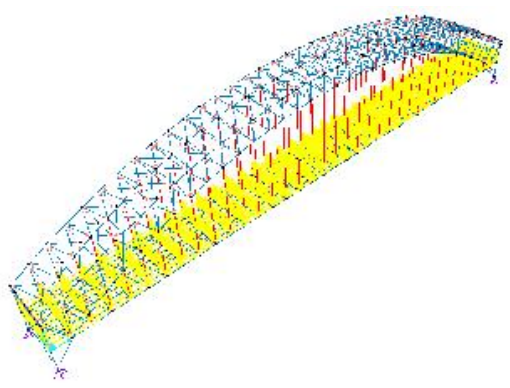

Gambar 14. Pembebanan Beban Mati Sumber: Hasil Analisa

\section{Beban Lalu Lintas}
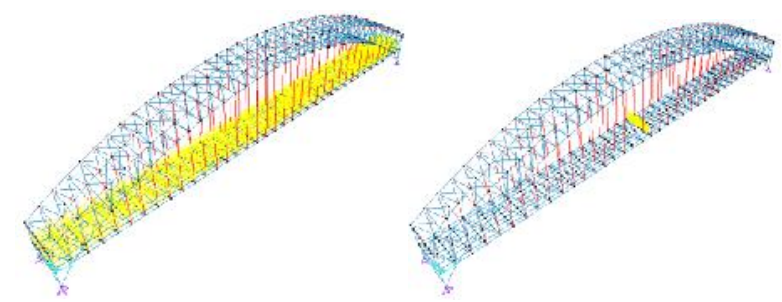

Gambar 15. Permodelan Beban Lalu Lintas BTR (kiri) dan BGT (kanan)

Sumber: Hasil Analisa

\section{Beban Gempa}

Beban gempa direncanakan berdasarkan RSNI 2833:2016[7] dengan menggunakan metode analisa gempa respon spectrum pada level gempa terlampaui $7 \%$ dalam 75 tahun
(1000 tahun). Data tanah yang digunakan sebagaimana disajikan pada tabel 3.

Tabel 3. Data Tanah (A1) Jembatan Sembayat

\begin{tabular}{ccc}
\hline Lapisan & Tbl. Lapisan (di) & N-SPT (Ni) \\
\hline 1 & 1000 & 0 \\
2 & 4000 & 10 \\
3 & 12500 & 9.50 \\
4 & 7500 & 36.50 \\
5 & 2000 & 30 \\
6 & 2000 & 24 \\
7 & 7500 & 33.33 \\
8 & 43500 & 30 \\
\hline TOTAL & 80000 & 110 \\
\hline
\end{tabular}

Dari data tanah diatas dan lokasi jembatan yang terletak di kabupaten Gresik, maka didapatkan nilai sebagai berikut:

$$
\begin{array}{ll}
\mathrm{PGA} & =0,25 \\
\mathrm{~S}_{\mathrm{S}} & =0,5 \\
\mathrm{~F}_{\mathrm{PGA}} & =1,3 \\
\mathrm{~S}_{1} & =0,25 \\
\mathrm{~F}_{\mathrm{V}} & =1,9 \\
\mathrm{maka} ; & \\
\mathrm{A}_{\mathrm{S}} & =\mathrm{F}_{\mathrm{PGA}} \times \mathrm{PGA}=1,3 \times 0,25=0,325 \\
\mathrm{~S}_{\mathrm{DS}} & =\mathrm{F}_{\mathrm{a}} \times \mathrm{S}_{\mathrm{S}}=1,3 \times 0,5=0,65 \\
\mathrm{~S}_{\mathrm{D} 1} & =\mathrm{F}_{\mathrm{V}} \times \mathrm{S}_{1}=1,9 \times 0,25=0,475 \\
\mathrm{~T}_{\mathrm{S}} & =\frac{S_{D 1}}{S_{D S}}=\frac{0,475}{0,65}=0,73077 \\
\mathrm{~T}_{0} & =0,2 \mathrm{~T}_{\mathrm{S}}=0,2.0,7308=0,14615
\end{array}
$$

Zona gempa $3\left(0,3<\mathrm{S}_{\mathrm{D} 1}<0,5\right)$

Dari perhitungan perioda di atas diperoleh grafik respon spectrum sebagaimana ditunjukkan pada gambar 16. Nilai respon spektrum pada gambar 16 diinput pada SAP2000 dengan kombinasi pembebanan sebagai berikut:

$$
\begin{aligned}
& \mathrm{DL}+0,5 \mathrm{LL}+\mathrm{EQx}+0,3 \mathrm{EQy} \\
& \mathrm{DL}+0,5 \mathrm{LL}+0,3 \mathrm{EQx}+\mathrm{EQy}
\end{aligned}
$$

Perencanaan busur atas menggunakan profil box $900 \times 700 \times$ 50. Berdasarkan hasil analisa SAP2000 diambil sampel frame dengan tekan maksimum pada frame 223 sebagai berikut:

$$
\begin{aligned}
\mathrm{Mx} & =826,845 \mathrm{kNm} \\
\mathrm{My} & =-167.981 \mathrm{kNm} \\
\mathrm{V} & =-34.742 \mathrm{kN} \\
\mathrm{N} & =25492,824 \mathrm{kN}
\end{aligned}
$$




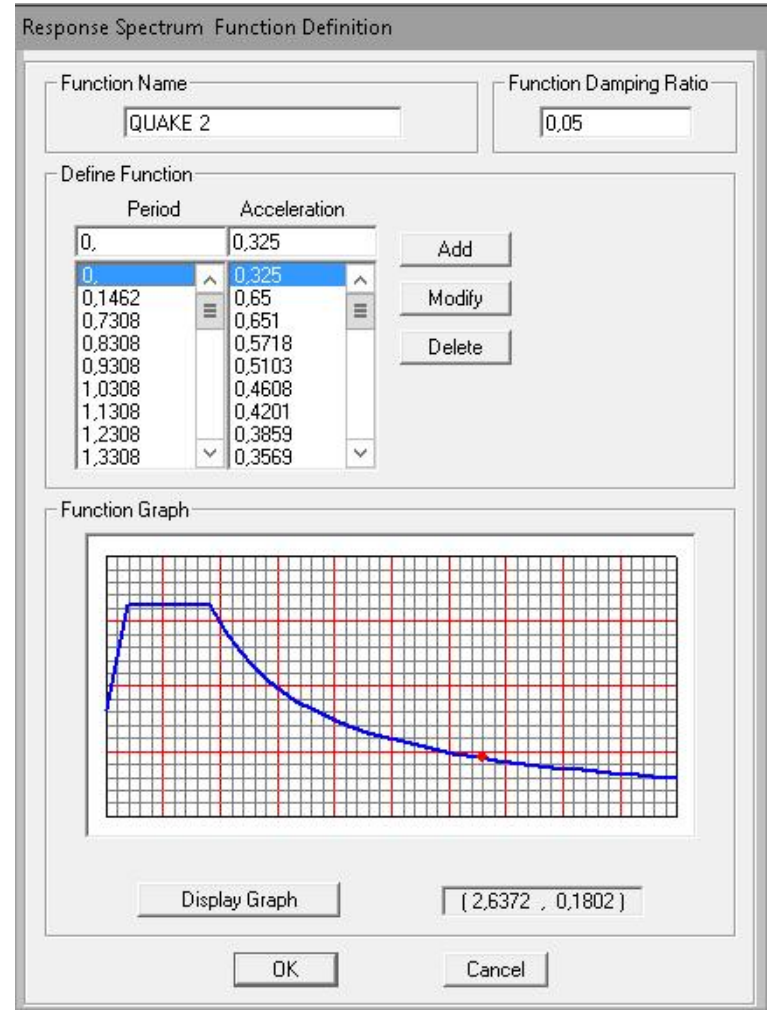

Gambar 16. Respon Spektrum Gempa Sumber: Hasil Analisa

\section{Perencanaan Busur Atas}

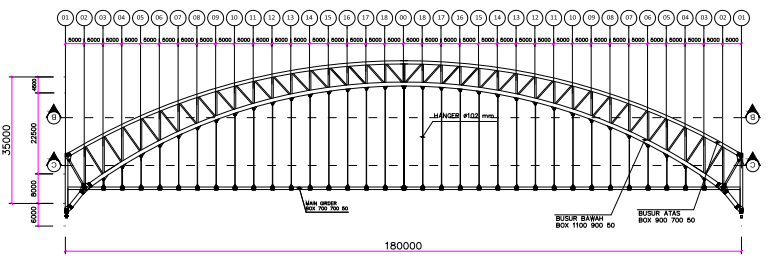

Gambar 17. Elemen Struktur Utama

Sumber: Hasil Analisa

Pada elemen busur atas menerima gaya tekan yang cukup besar pada bagian tengah bentang, dengan kuat nominal penampang tekan sebesar $61142.242 \mathrm{kN}$ dan kuat nominal penampang lentur sebesar $19926 \mathrm{kNm}$, penampang mampu menahan gaya yang terjadi.

\section{Perencanaan Cable Rod}

Kabel penggantung menggunakan Cable Rod tipe M520 (M105) carbon steel dengan spesifikasi diameter cable $(\phi)=$ $105 \mathrm{~mm}$, berat kabel $(\mathrm{w})=32 \mathrm{~kg} / \mathrm{m}$, minimum break load $=$ $5279 \mathrm{kN}$ dengan kabel terpanjang $=30,5 \mathrm{~m}$.

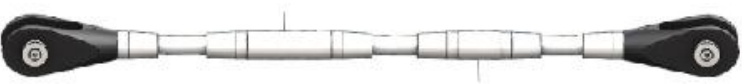

Gambar 18. Kabel Tipe M520 (M105)

Sumber: Maccalaoy Cable Rod

Perencanaan kabel harus memenuhi syarat kelangsingan berdasarkan RSNI T-03-2005 [2] sebagai berikut:

$\frac{L}{D}<500$

$\frac{30500 \mathrm{~mm}}{105 \mathrm{~mm}}<500$

$290,476<500$

(Memenuhi)

Kontrol kekuatan kabel,

\section{$\mathrm{Pu}<$ Minimum Break Load}

$1720,389 \mathrm{kN} \quad<50279 \mathrm{kN}$

(Memenuhi)

Jadi, cable rod tipe 520 (M105) carbon steel bisa digunakan.

\section{Perencanaan Komponen Sekunder Jembatan}

Perencanaan komponen sekunder jembatan busur terdiri perencanaan ikatan angin lantai kendaraan, ikatan angin rangka busur dan portal akhir.

1. Beban Angin

Perencanaan beban angin mengacu pada SNI 1725:2016 psl. 9.6. [4] Titik-titik yang dikenai beban angin tekan untuk rangka busur atas dan bawah ditunjukkan pada gambar 19 .

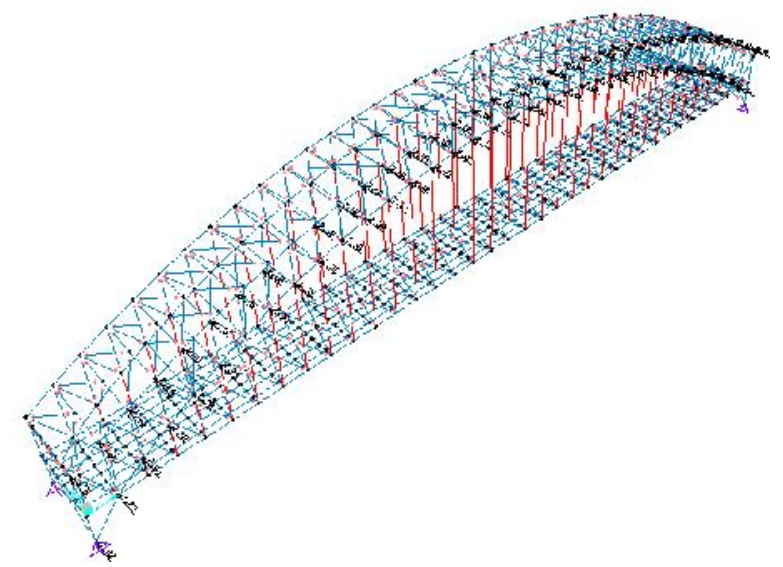

Gambar 19. Beban Angin Pada Rangka Busur Sumber: Hasil Analisa 
2. Ikatan Angin Lantai Kendaraan

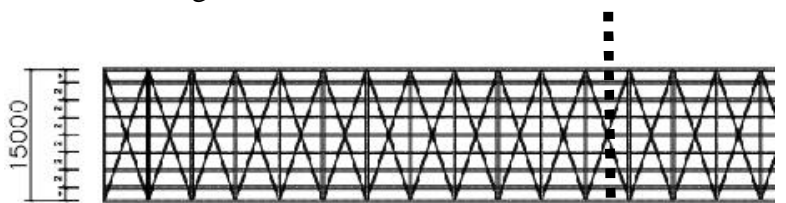

$\left.\left.\left.\left.\left.\left.\left.\left.\left.\left.\left.\left.\left.\left.{ }_{5000}^{50003}\right|^{5000}\right|^{5000}\right|^{5000}\right|^{5000}\right|^{500 C}\right|^{5000}\right|^{5030}\right|^{5000}\right|^{5000}\right|^{5000}\right|^{5003}\right|^{5000}\right|^{5000}\right|^{5}$

Gambar 20. Ikatan Angin Bawah

Sumber: Hasil Analisa

Ikatan angin bawah (gambar 20) direncanakan menggunakan profl box $250 \times 250 \times 12$.

Berdasarkan hasil analisa SAP2000, diambil sampel frame dengan aksial maksimum pada frame 1294 sebagai berikut,

$$
\begin{array}{ll}
\mathrm{N} \text { tarik } & =2476,976 \mathrm{kN} \\
\mathrm{N} \text { tekan } & =-2045,036 \mathrm{kN}
\end{array}
$$

Ikatan angin bawah menerima gaya yang cukup besar pada daerah tumpuan, karena dikenai gaya gempa yang cukup besar. Profil ikatan angin bawah memiliki kuat nominal tekan sebesar 3572,066 kN dan kuat nominal tarik sebesar $3874,406 \mathrm{kN}$, sehingga penampang box ikatan angin bawah mampu menahan beban yang ada.

3. Portal Akhir

Portal akhir merupakan elemen struktur yang meneruskan gaya dari konstruksi busur ke tumpuan. Analisa struktur portal akhir dihitung sebagai hubungan balok kolom pada konstruksi baja (gambar 21).

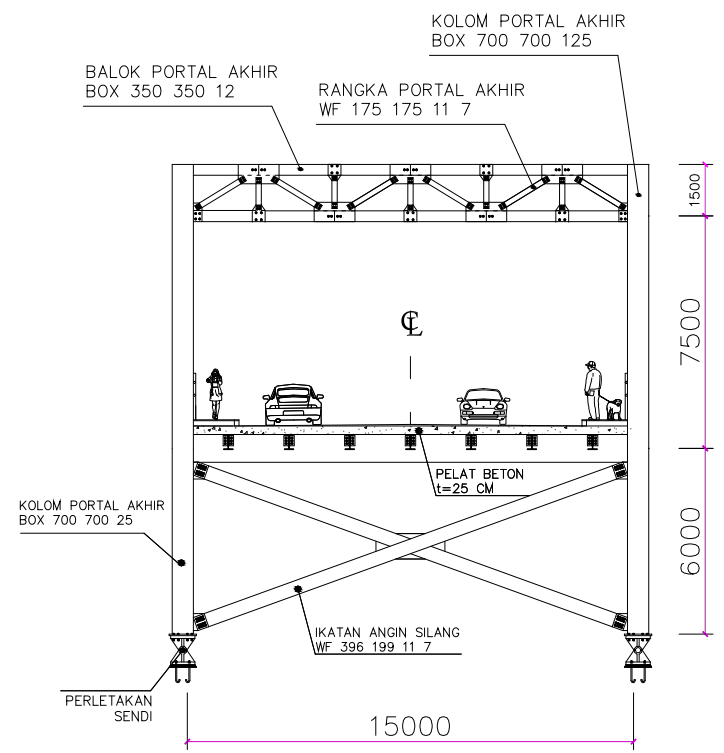

Gambar 21. Portal Akhir Jembatan

Sumber: Hasil Analisa

Kolom portal akhir direncanakan menggunakan profil box $700 \times 700 \times 25$. Berdasarkan hasil analisa SAP2000 diambil sampel frame dengan tekan maksimum pada frame 1822 sebagai berikut:

$$
\begin{aligned}
\mathrm{Mx} & =-58,864 \mathrm{kNm} \\
\mathrm{My} & =-167.981 \mathrm{kNm} \\
\mathrm{V} & =-7.442 \mathrm{kN} \\
\mathrm{N} & =-732.897 \mathrm{kN}
\end{aligned}
$$

Penampang yang digunakan mampu menahan beban yang terjadi tanpa adanya penambahan momen, karena nilai $\delta_{\mathrm{bx}}=$ $0,85<1$. Nilai kuat nominal tekan sebesar $=1202,556 \mathrm{kNm}$ dengan kuat lentur nominal $=535185944,4 \mathrm{~N}$.

Untuk balok portal akhir yang menggunakan sistem rangka direncanakan menggunakan profl box $350 \times 350 \times 12$ sebagai balok utama.

\section{Detail Sambungan}

Spesifikasi yang digunakan mengacu pada specification for structural steel building AISC 2010 section J3 hal. 120-

\begin{tabular}{|c|c|c|c|c|}
\hline \multirow[t]{5}{*}{ Baut } & \multirow[t]{5}{*}{ M30 } & $\varnothing$ & 33 & $\mathrm{~mm}^{2}$ \\
\hline & & $\mathrm{Ab}$ & 856 & $\mathrm{~mm}^{2}$ \\
\hline & & $\mathrm{Tb}$ & 408 & $\mathrm{kN}$ \\
\hline & & Fnt & 780 & $\mathrm{MPa}$ \\
\hline & & Fnv & 579 & $\mathrm{MPa}$ \\
\hline \multicolumn{5}{|c|}{ Pelat siku penyambung $=\mathrm{L} 41041010$} \\
\hline & fy & \multicolumn{3}{|c|}{$=290 \mathrm{MPa}$} \\
\hline & $\mathrm{fu}$ & \multicolumn{3}{|c|}{$=500 \mathrm{MPa}$} \\
\hline Bidang geser & (n) & \multicolumn{3}{|l|}{$=2$} \\
\hline
\end{tabular}
122. [9]

1. Sambungan Gelagar Memanjang

Pada sambungan gelagar memanjang (gambar 22) digunakan baut M30 dengan detail seperti tabel 4.

Tabel 4. Baut M30

Besarnya gaya dalam hasil output program SAP adalah sebagai berikut:

$\begin{array}{ll}\mathrm{Mx} & =509,681 \mathrm{kNm} \\ \mathrm{V} & =344,343 \mathrm{kN} \\ \mathrm{N} & =1198.308 \mathrm{kN}\end{array}$

Baut yang digunakan merupakan tipe baut yang mengalami tarik dimana kuat ijin satu baut diambil dari nilai terkecil dari perhitungan kuat nominal baut [7]. Diambil nilai kuat nominal baut paling kecil, $\mathrm{R}_{\mathrm{n}}=408,498 \mathrm{kN}$, sehingga jumlah baut yang digunakan adalah sebagai berikut:

$$
\begin{aligned}
\mathrm{n} & =\frac{1198.308 \mathrm{kN}}{0,75 \times 408,498 \mathrm{kN}} \\
& =3,911=4 \mathrm{buah}
\end{aligned}
$$

Susunan baut dan jarak antar lubang baut didasarkan pada batasan berikut:

Smin $<\mathrm{S}<\mathrm{Smax}$ 
$2.2 / 3 \mathrm{db}<\mathrm{S}<12 \mathrm{tp}$

$2.2 / 3 \times 33 \mathrm{~mm}<90 \mathrm{~mm}<12 \times 10 \mathrm{~mm}$

$44 \mathrm{~mm}<90 \mathrm{~mm}<120 \mathrm{~mm}$

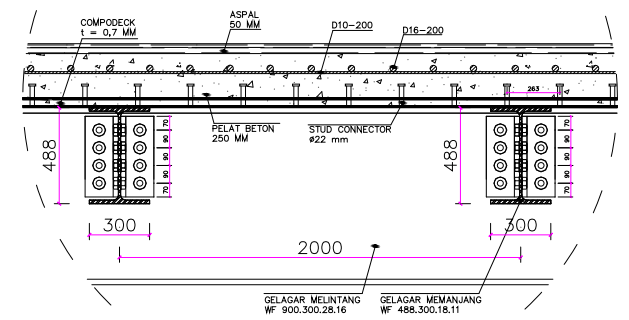

Gambar 22. Detail Sambungan Gelagar Memanjang Sumber: Hasil Analisa

2. Sambungan Gelagar Melintang

Untuk sambunga pada gelagar melintang digunakan spesifikasi baut yang sama dengan sambungan gelagar memanjang (gambar 23). Output gaya dalam dari output program SAP adalah sebagai berikut:

$$
\begin{array}{ll}
\mathrm{Mx} & =4716,508 \mathrm{kNm} \\
\mathrm{V} & =1524,287 \mathrm{kN} \\
\mathrm{N} & =-805,249 \mathrm{kN}
\end{array}
$$

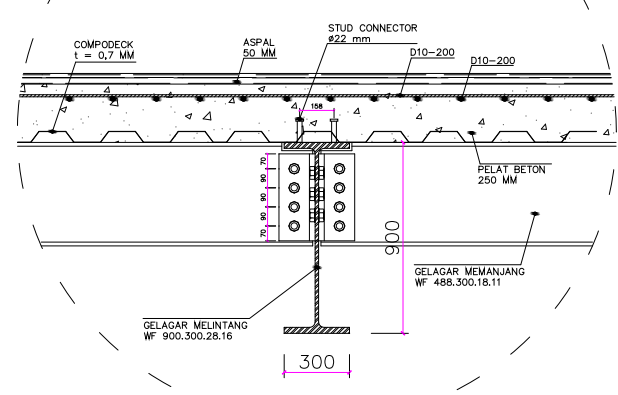

Gambar 23. Detail Sambungan Gelagar Melintang Sumber: Hasil Analisa

Jumlah baut yang digunakan adalah,

$\mathrm{n} \quad=\frac{1524,287 \mathrm{kN}}{0,75 \times 461,04 \mathrm{kN}}$

$$
=2,329=3 \text { buah }
$$

Susunan dan jarak baut sebagai berikut:

Smin $<$ S $<$ Smax

$44 \mathrm{~mm}<90 \mathrm{~mm}<120 \mathrm{~mm}$

3. Sambungan Busur

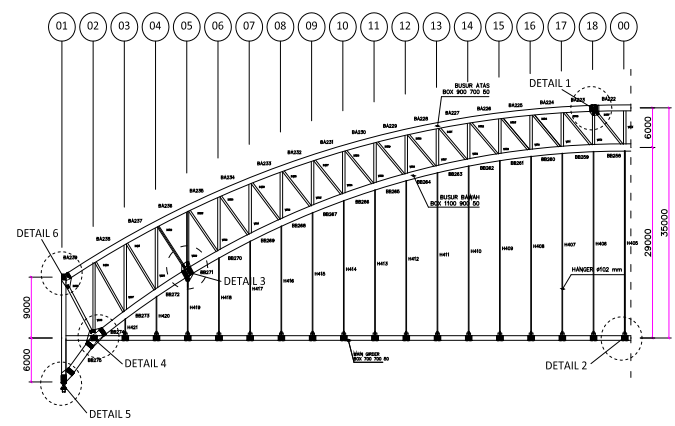

Gambar 24. Perencanaan Sambungan Busur Sumber: Hasil Analisa

\begin{tabular}{|c|c|c|c|c|}
\hline \multirow[t]{5}{*}{ Baut } & M30 & $\varnothing$ & 33 & $\mathrm{~mm}^{2}$ \\
\hline & & $\mathrm{Ab}$ & 856 & $\mathrm{~mm}^{2}$ \\
\hline & & $\mathrm{Tb}$ & 408 & $\mathrm{kN}$ \\
\hline & & Fnt & 780 & $\mathrm{MPa}$ \\
\hline & & Fnv & 579 & $\mathrm{MPa}$ \\
\hline
\end{tabular}

Data yang digunakan untuk perencanaan sambungan busur atas adalah seperti tabel 5 .

Tabel 5. Baut M30

Pelat penyambung

$$
\begin{array}{ll}
\mathrm{t} & =20 \mathrm{~mm} \\
\mathrm{fu} & =550 \mathrm{MPa}
\end{array}
$$$$
\text { Bidang geser (n) } \quad=2
$$

Desain sambungan busur atas mengambil sampel pada detail 1 pada gambar 26, yang dianggap mewakili keseluruhan kondisi busur atas dengan nilai gaya dalam yang diambil dari SAP2000 sebagai berikut:

$\mathrm{Mx} \quad=826,446 \mathrm{kNm}$

$\mathrm{My} \quad=207,157 \mathrm{kNm}$

$\mathrm{V} \quad=114,359 \mathrm{kN}$

$\mathrm{N} \quad=-25492,824 \mathrm{kN}$

Kuat ijin satu baut diambil dari nilai terkecil dari perhitungan kuat nomnimal baut berikut, section J.3 [9], $\mathrm{R}_{\mathrm{n}}=461,04 \mathrm{kN}$

Jumlah baut direncanakan sebagai berikut:

Beban yang bekerja searah $\mathrm{x}(\mathrm{Rx})$

$\frac{M x}{H} \quad=\frac{826,446 \mathrm{kNm}}{0,9}=918,273 \mathrm{kN}$ 


$$
\begin{aligned}
\frac{M y}{B} & =\frac{207,157 \mathrm{kNm}}{0,7}=295,938 \mathrm{kN} \\
\text { Rx tot } & =918,273+295,938+25492,824 \\
& =26707,036 \mathrm{kN}
\end{aligned}
$$

Pada web

$$
\begin{aligned}
\mathrm{R}_{\mathrm{web}} & =\frac{H}{H+B} \times \frac{1}{2} \times R x \\
& =\frac{0,9}{0,9+0,7} \times \frac{1}{2} \times 26707,036 \mathrm{kN} \\
& =7511,354 \mathrm{kN} \\
\mathrm{n} & =\frac{7511,354 \mathrm{kN}}{0,75 \times 461,04 \mathrm{kN}} \\
& =21,723=22 \text { buah }
\end{aligned}
$$

Pada flens

$$
\begin{aligned}
\mathrm{R}_{\mathrm{web}} & =\frac{B}{H+B} \times \frac{1}{2} \times R x \\
& =\frac{0,7}{0,9+0,7} \times \frac{1}{2} \times 26707,036 \mathrm{kN} \\
& =5842,164 \mathrm{kN} \\
\mathrm{n} & =\frac{5842,164 \mathrm{kN}}{0,75 \times 461,04 \mathrm{kN}} \\
& =16.896=17 \text { buah }
\end{aligned}
$$

Susunan baut dan jarak antar lubang baut direncanakan sebagai berikut:

Smin $<\mathrm{S}<\mathrm{Smax}$

$2.2 / 3 \mathrm{db}<\mathrm{S}<12 \mathrm{tp}$

$2.2 / 3 \times 33 \mathrm{~mm}<90 \mathrm{~mm}<12 \times 10 \mathrm{~mm}$

$44 \mathrm{~mm}<100 \mathrm{~mm}<120 \mathrm{~mm}$

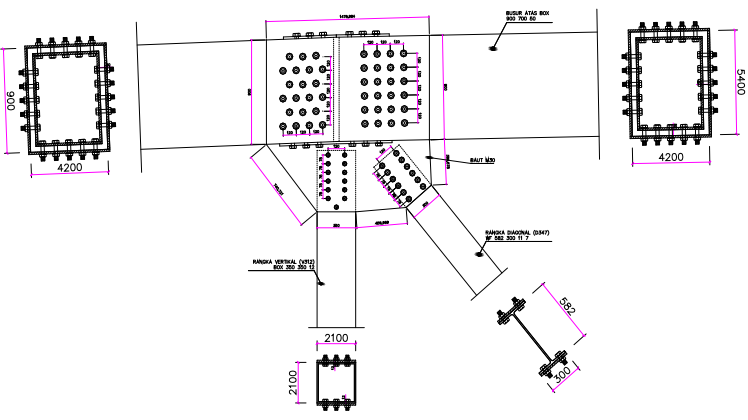

Gambar 25. Detail Sambungan Busur Atas

Sumber: Hasil Analisa

Untuk sambungan busur vertikal direncanakan menggunakan baut M30 juga, jumlah baut disajikan pada tabel 6 . Sambungan busur vertikal menggunakan baut M30, jumlah baut disajikan pada tabel 7 .

\section{Perletakan Jembatan}

Pada perencanaan bentang utama jembatan direncanakan menggunakan perletakan rol pada abutment dan perletakan sendi pada pilar [3].
Tabel 6. Rekapitulasi Jumlah Baut Rangka Busur Vertikal

\begin{tabular}{cccc}
\hline Frame & $\begin{array}{c}\mathrm{Nu} \\
(\mathrm{kN})\end{array}$ & $\begin{array}{c}\mathrm{Rn} \\
(\mathrm{kN})\end{array}$ & $\begin{array}{c}\text { Jumlah Baut } \\
(\mathrm{n})\end{array}$ \\
\hline V 296 & -1543.45 & 230.52 & 9 \\
V 297 & -2250.18 & 230.52 & 14 \\
V 298 & -2794.26 & 230.52 & 17 \\
V 299 & -3213.51 & 230.52 & 19 \\
V 300 & -3409.94 & 230.52 & 20 \\
V 301 & -3520.6 & 230.52 & 21 \\
V 302 & -3511.32 & 230.52 & 21 \\
V 303 & -3404.67 & 230.52 & 20 \\
V 304 & -3218.68 & 230.52 & 19 \\
V 305 & -2962.42 & 230.52 & 18 \\
V 306 & -2642.95 & 230.52 & 16 \\
V 307 & -2270.05 & 230.52 & 14 \\
V 308 & -1847.41 & 230.52 & 11 \\
V 309 & -1505.67 & 230.52 & 9 \\
V 310 & -1158.41 & 230.52 & 7 \\
V 311 & -749.997 & 230.52 & 5 \\
V 312 & 794.429 & 230.52 & 5 \\
V 313 & 736.963 & 230.52 & 5 \\
\hline & & &
\end{tabular}

Tabel 7. Rekapitulasi jumlah baut rangka busur diagonal

\begin{tabular}{cccc}
\hline Frame & $\begin{array}{c}\text { Nu } \\
(\mathrm{kN})\end{array}$ & $\begin{array}{c}\mathrm{Rn} \\
(\mathrm{kN})\end{array}$ & $\begin{array}{c}\text { Jumlah Baut } \\
(\mathrm{n})\end{array}$ \\
\hline D 347 & 2202.83 & 230.52 & 13 \\
D 348 & 2663.14 & 230.52 & 16 \\
D 349 & -5269.71 & 230.52 & 31 \\
D 350 & -5394.38 & 230.52 & 32 \\
D 351 & 1818.97 & 230.52 & 11 \\
D 352 & 2398.86 & 230.52 & 14 \\
D 353 & 2835.87 & 230.52 & 17 \\
D 354 & 3195.19 & 230.52 & 19 \\
D 355 & 3627.58 & 230.52 & 21 \\
D 356 & 3989.78 & 230.52 & 24 \\
D 357 & 4228.28 & 230.52 & 25 \\
D 358 & 4336.88 & 230.52 & 26 \\
D 359 & 4284.24 & 230.52 & 25 \\
D 360 & 4082.56 & 230.52 & 24 \\
D 361 & 3823.7 & 230.52 & 23 \\
D 362 & 3550.89 & 230.52 & 21 \\
D 363 & 3324.14 & 230.52 & 20 \\
D 364 & 3207.03 & 230.52 & 19 \\
\hline
\end{tabular}


1. Perletakan Rol

Dari hasil analisa dengan program SAP2000, reaksi perletakan pada rol adalah sebagai berikut,

$$
\begin{array}{ll}
\mathrm{V} & =22338,1804 \mathrm{kN} \\
\mathrm{Hx} & =0 \\
\mathrm{Hy} & =1910,770 \mathrm{kN} \\
\mathrm{R} & =\frac{22338,1804^{2}+1910,770^{2}}{22419,753 \mathrm{kN}}
\end{array}
$$

Detail perencanaan perletakan rol sesuai dengan reaksi diatas ditunjukkan pada detail gambar 26.
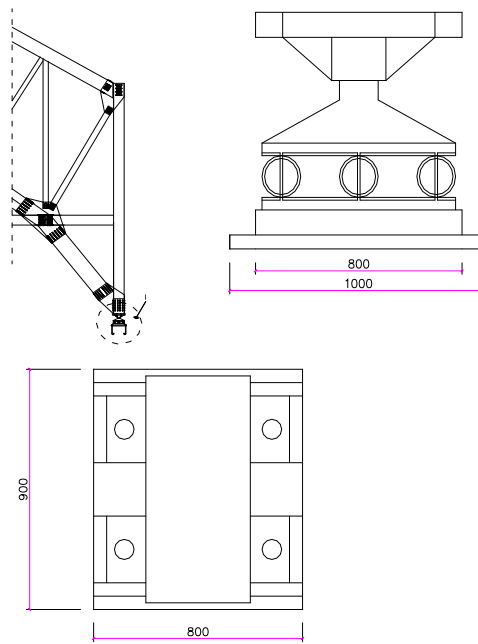

Gambar 26. Detail Perencanaan Perletakan Rol Sumber: Hasil Analisa

\section{Perletakan Sendi}

Untuk reaksi perletakan pada sendi, hasil analisa dengan program SAP2000 adalah sebagai berikut:

$$
\begin{array}{lll}
\mathrm{V} & =27157.384 \quad \mathrm{kN} \\
\mathrm{Hx} & =29754.115 \quad \mathrm{kN} \\
\mathrm{R} & =\sqrt{27157.384^{2}+29754.115^{2}} \\
& =3258.67 \mathrm{kN}
\end{array}
$$

Desain preletakan sendi ditunjukkan pada gambar 277. Lendutan maksimum berdasarkan analisa program SAP2000 terjadi pada kombinasi 2 di tengah bentang sebesar $21,08 \mathrm{~cm}$. Kontrol;

$$
\begin{aligned}
21,08 \mathrm{~cm} & <\frac{L}{800} \\
21,08 \mathrm{~cm} & <\frac{18000 \mathrm{~cm}}{800} \\
21,08 \mathrm{~cm} & <22,5 \mathrm{~cm}
\end{aligned}
$$

(Memenuhi) (gambar 28)
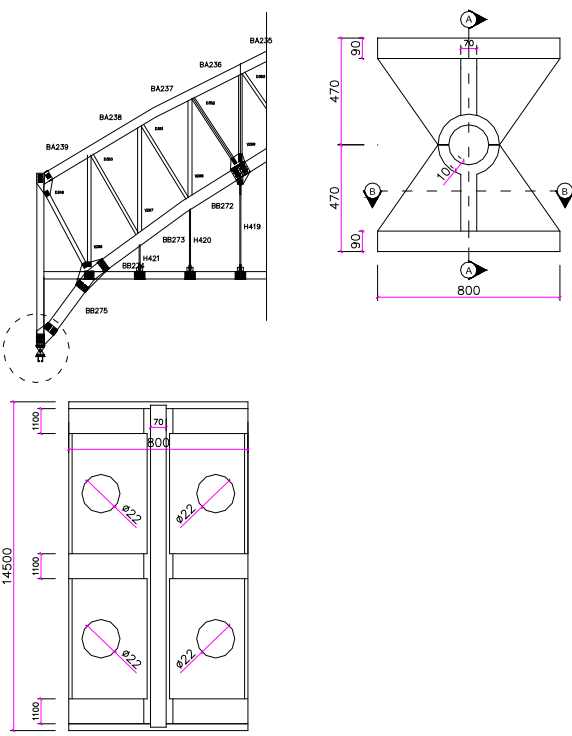

Gambar 27. Detail Perencanaan Perletakan Sendi Sumber: Hasil Analisa

\section{Kontrol Lendutan Jembatan}

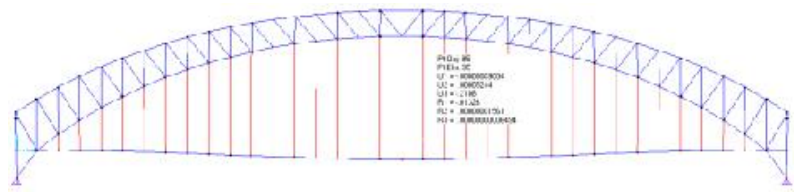

Gambar 28. Lendutan yang terjadi Sumber: Hasil Analisa

\section{Perencanaan Bangunan Bawah}

1. Abutment

- Data perencanaan abutment (gambar 29)

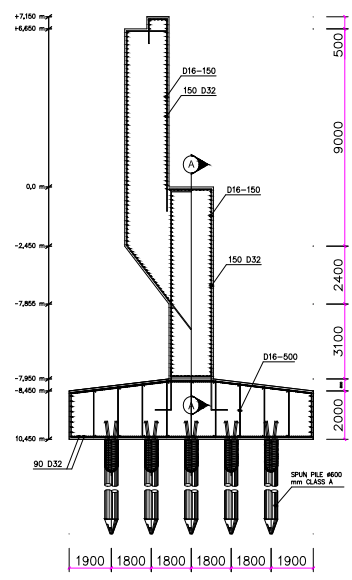

Gambar 29. Preliminary Design Abutment Sumber: Hasil Analisa 


$\begin{array}{ll}\text { Tinggi total rencana (h) } & =15 \mathrm{~m} \\ \text { Tebal dinding abutment (b) } & =2 \mathrm{~m} \\ \text { Mutu beton (fc') } & =30 \mathrm{Mpa} \\ \text { Mutu tulangan (fy) } & =400 \mathrm{Mpa} \\ \text { Diameter tul. lentur } & =32 \mathrm{~mm} \\ \text { Diameter tul. confinement } & =16 \mathrm{~mm}\end{array}$

- Pembebanan pada abutment I (gambar 30)

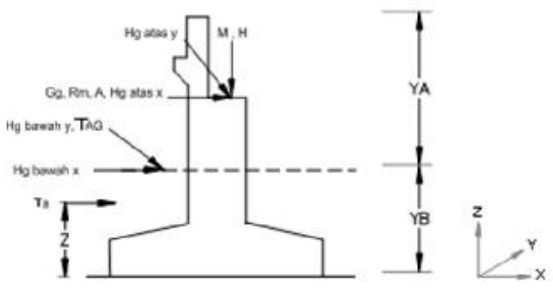

Gambar 30. Sketsa Pembebanan pada Abutment Sumber: Hasil Analisa

Tabel 8. Rekapitulasi pembebanan abutment

\begin{tabular}{|c|c|c|c|c|c|}
\hline No. & Uraian & $\begin{array}{c}\mathrm{V} \\
(\mathrm{kN})\end{array}$ & $\begin{array}{c}\mathrm{Hx} \\
(\mathrm{kN})\end{array}$ & $\begin{array}{c}\mathrm{Mx} \\
(\mathrm{kNm})\end{array}$ & $\begin{array}{c}\text { My } \\
(\mathrm{kNm})\end{array}$ \\
\hline \multirow[t]{5}{*}{1} & Beban permanen & & & & \\
\hline & Struktur atas & 21482 & & 4048 & \\
\hline & Abutment & 22804 & & & 16675 \\
\hline & Tekanan tanah & & 14590 & & -78183 \\
\hline & $\begin{array}{l}\text { Tekanan tanah } \\
\text { akbt gempa }\end{array}$ & & 12300 & & 58979 \\
\hline \multirow[t]{4}{*}{2} & Beban Lalu Lintas & & & & \\
\hline & Beban "D" & 6997 & & 1704 & \\
\hline & Beban Rem & & 592 & & 6186 \\
\hline & Gaya gesek & & 4271 & & 40797 \\
\hline \multirow[t]{4}{*}{3} & Aksi Lingkungan & & & & \\
\hline & EQ struktur atass & 643 & 3879 & 29094 & 3252 \\
\hline & EQ abutment & & 2607 & 12503 & 12503 \\
\hline & Beban Angin & 20 & 37 & 239 & 395 \\
\hline
\end{tabular}

Dari tabel 8 perhitungan pembebanan, diperoleh nilai stabilitas abutment sebagai berikut,
M guling
$=78183.849 \mathrm{kNm}$
M penahan
$=142240.653 \mathrm{kNm}$

Dimana, stabilitas penahan abutment harus memenuhi persyaratan berikut;

$$
\begin{aligned}
\mathrm{SF} & =\frac{\sum \text { M penahan }}{\sum \text { MGuling }}>1,5 \\
& =\frac{78183.849 \mathrm{kNm}}{142240.653 \mathrm{kNm}}>1,5 \\
& =1.819>1,5
\end{aligned}
$$

Kontrol selanjutnya adalah kontrol geser abutment, yang harus memenuhi syarat berikut:

$$
\mathrm{SF} \quad=\frac{\sum R h}{\sum P} \geq 1,5
$$

$$
\begin{aligned}
& =\frac{7,745 \times 165+44286.415 \times 0.510}{33377.539} \geq 1,5 \\
& =0,7<1,5
\end{aligned}
$$

(Tidak Memenuhi)

Karena abutment tidak dapat menahan gaya geser yang terjadi, maka diperlukan pondasi tiang pancang untuk menambah ketahanan terhadap geser yang terjadi.

- Penulangan dinding abutment (gambar 31)

Penulangan menggunakan SP-Coloumn.

Untuk ps. 5.7.8.1 bahwa rasio dari tulangan memanjang kurang dari 0,01 Ag dan > 0,08 Ag.[5]
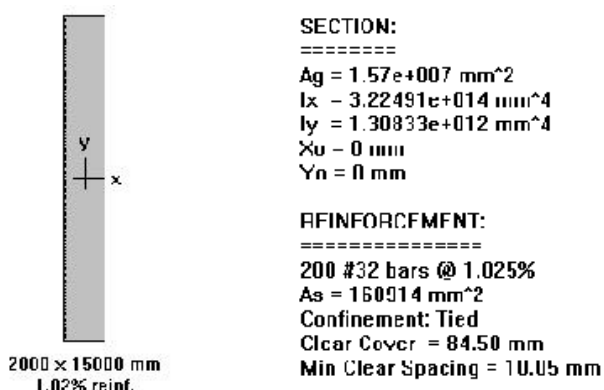

Gambar 31. Desain Penulangan Dinding Abutment Sumber: Hasil Analisa

- Perhitungan daya dukung tiang

\begin{tabular}{|c|c|c|c|c|}
\hline \multirow{2}{*}{$\begin{array}{c}\text { Ou ter Dameter of Pilss } \\
0 \\
\text { (mmin) }\end{array}$} & \multirow{2}{*}{$\begin{array}{c}\text { Wall Thiceness } \\
T \\
(\mathrm{mim})\end{array}$} & \multirow{2}{*}{$\begin{array}{l}\text { Sp ral Wire } \\
\text { Ciameler } \\
\text { (mmin) }\end{array}$} & \multicolumn{2}{|c|}{ Pitch } \\
\hline & & & Znne 1 ( $(\mathrm{mm})$ & Znne $12(\mathrm{~mm})$ \\
\hline 300 & 50 & 3.2 & so & 100 \\
\hline 350 & 70 & 3. & 50 & 100 \\
\hline 400 & is & 3.2 & so & 100 \\
\hline$\angle 50$ & 80 & 4.0 & 50 & 100 \\
\hline 500 & 20 & 4.0 & so & 00 \\
\hline 600 & 100 & 4.9 & 50 & 100 \\
\hline
\end{tabular}

Perhitungan daya dukung pondasi tiang pancang meliputi kapasitas aksial dari kekuatan daya dukung tanah yang ada dengan menggunakan metode Luciano Decourt. Menggunakan tiang pancang produksi PT. Wika Beton (gambar 32).

Gambar 32. Spesifikasi Tiang Pancangan

Penambahan pondasi tiang pancang pada abutment direncanakan sebagai berikut,

$\begin{array}{ll}\text { Allowable axial } & =223 \mathrm{t} \\ \text { Jarak tiang pancang } & =3 \mathrm{D} \\ & =3 \times 0,6=1,8 \mathrm{~m} \\ \mathrm{n} \text { (jumlah pile) } & =45 \mathrm{buah} \\ \text { Kedalaman rencana } & =58 \mathrm{~m} \\ \mathrm{Q}_{\mathrm{L}} & =214,071 \mathrm{t}\end{array}$

Kontrol, 
$214,07 \mathrm{t}<$ $223 \mathrm{t}$

(Memenuhi)

2. Pilar

- Data perencanaan pilar (gambar 33)

Tinggi dinding rencana $(\mathrm{h})=6 \mathrm{~m}$
Tebal pilar
(b) $\quad=1,5 \mathrm{~m}$
Mutu beton
$\left(\mathrm{fc}{ }^{\prime}\right) \quad=30 \mathrm{Mpa}$
Mutu tulangan
(fy) $\quad=400 \mathrm{Mpa}$
Diameter tul. lentur $=32 \mathrm{~mm}$

Diameter tul. confinement $=16 \mathrm{~mm}$

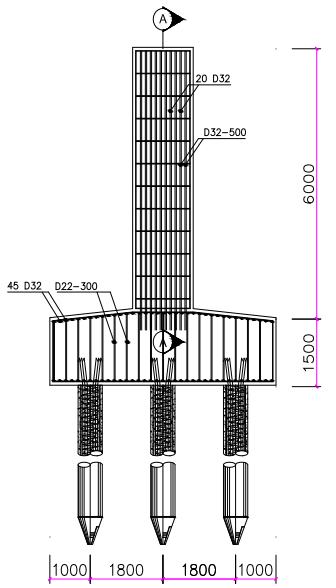

Gambar 33. Preliminary Design Pilar Sumber: Hasil Analisa

- Pembebanan pilar (gambar 34 dan tabel 9)

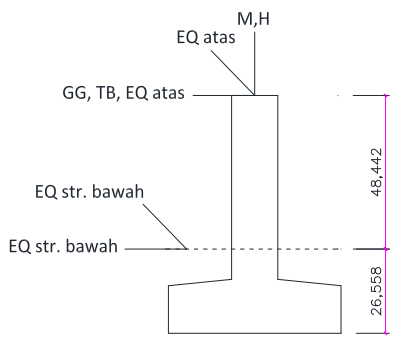

Gambar 34. Sketsa Pembebanan Pada Pilar Sumber: Hasil Analisa

Dari kombinasi pembebanan yang sudah dilakukan, diperoleh gaya-gaya maksimum yang bekerja pada pilar sebagai berikut,

$$
\begin{array}{ll}
\mathrm{V} & =44676.361 \mathrm{kN} \\
\mathrm{Hx} & =9477.346 \mathrm{kN} \\
\mathrm{Hy} & =1910.770 \mathrm{kN} \\
\mathrm{Mx} & =44676.361 \mathrm{kNm} \\
\mathrm{My} & =75442.554 \mathrm{kNm}
\end{array}
$$

\section{- Penulangan pilar}

\begin{tabular}{|c|c|c|c|c|c|c|}
\hline No. & Uraian & $\begin{array}{c}\mathrm{V} \\
(\mathrm{kN})\end{array}$ & $\begin{array}{c}\mathrm{Hx} \\
(\mathrm{kN})\end{array}$ & $\begin{array}{c}\mathrm{Hy} \\
(\mathrm{kN})\end{array}$ & $\begin{array}{c}\mathrm{Mx} \\
(\mathrm{kNm})\end{array}$ & $\begin{array}{c}\mathrm{My} \\
(\mathrm{kNm})\end{array}$ \\
\hline \multirow[t]{3}{*}{1} & Beban Tetap & & & & & \\
\hline & Struktur Atas & 21488 & & 532 & 3994 & \\
\hline & Pilar & 6411 & & & & 211 \\
\hline \multirow[t]{4}{*}{2} & $\begin{array}{l}\text { Beban Lalu } \\
\text { Lintas }\end{array}$ & & & & & \\
\hline & Beban "D" & 6997 & & 227 & 1704 & \\
\hline & Beban Rem & & 592 & & & 6186 \\
\hline & Gaya Gesek & & 4272 & & & 40806 \\
\hline \multirow[t]{4}{*}{3} & Aksi Lingkungan & & & & & \\
\hline & $\begin{array}{l}\text { EQ Struktur } \\
\text { Atas }\end{array}$ & 643 & 3879 & 311 & 29094 & 3252 \\
\hline & EQ Pilar & & 733 & 733 & 1352 & 1352 \\
\hline & Beban Angin & 20 & 37 & 22 & 239 & 395 \\
\hline
\end{tabular}

Penulangan menggunakan SP-Coloumn (gambar 36).
Untuk ps. 5.7.8.1 bahwa rasio dari tulangan memanjang kurang dari 0,01 Ag dan >0,08 Ag. [5]

Tabel 9. Rekapitulasi pembebanan pilar

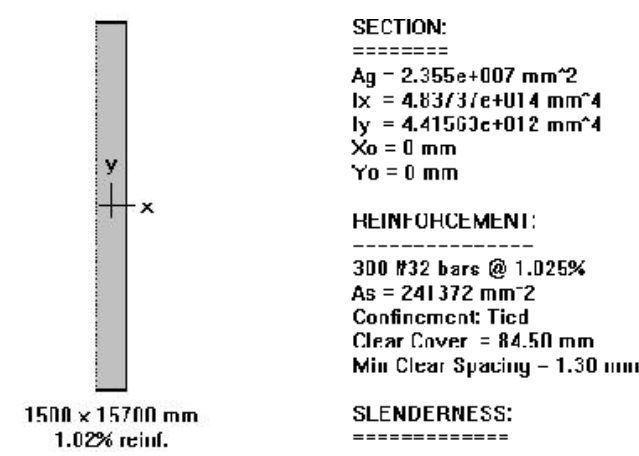

Gambar 35. Desain Penulangan Kolom Pilar Sumber: Hasil Analisa

- Perhitungan daya dukung tiang

Spesifikasi tiang pancang yang digunakan pada pilar sama dengan yang digunakan pada abutment. Perencanaan pondasi tiang pancang pada pilar dihitung sebagai berikut,

Dalam tiang pancang:

Allowable axial $\quad=223 \mathrm{t}$

Kedalaman rencana $\quad=59 \mathrm{~m}$

$\mathrm{n}$ (jumlah pile) $\quad=27$ buah

$\mathrm{Q}_{\mathrm{L}} \quad=185.922449 \mathrm{t}$

Syarat;

$185.92 \mathrm{t}<223 \mathrm{t}$

(Memenuhi)

Metode Pelaksanaan 
Metode pelaksanaan pembangunan duplikasi jembatan Sembayat ini direncanakan mengunakan metode balanced cantilever dengan dibantu tarikan kabel dan temporary tower yang dipasang pada tepi jembatan rencana. Analisa perhitungan metode dan tahapan pelaksanaan (staging analysis) menggunakan bantuan software SAP2000.

Perencanaan kabel penggantung (hanger) menggunakan cable tipe tension rods, yang dengan tipe M520, sedangkan pada pelaksanaan balanced cantilever, dalam setengah bentang dibagi menjadi 6 segmen, dimana setiap segmen sepanjang $3 \lambda=3 \times 5 \mathrm{~m}=15$ meter.

\section{Stage 1}

Panjang tarikan main span $=3 \lambda=3 \times 5 \mathrm{~m}=15$ meter dengan panjang tarikan side span $=38$ meter. $($ gambar 36$)$

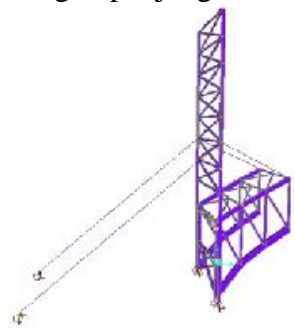

Gambar 36. Stage 1 Balanced Cantilever

\section{Stage 2}

Panjang tarikan main span $=6 \lambda=6 \times 5 \mathrm{~m}=30$ meter dengan panjang tarikan side span $=38$ meter. $($ gambar 37$)$

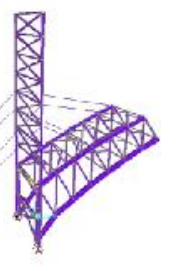

Gambar 37. Stage 2 Balanced Cantilever

\section{Stage 3}

Panjang tarikan main span $=9 \lambda=9 \times 5 \mathrm{~m}=45$ meter dengan panjang tarikan side span $=42$ meter. $($ gambar 38$)$

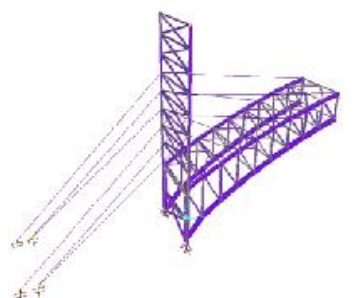

Gambar 38. Stage 3 Balanced Cantilever

\section{Stage 4}

Panjang tarikan main span $=3 \lambda=12 \times 5 \mathrm{~m}=60$ meter dengan panjang tarikan side span $=42$ meter. $($ gambar 39)

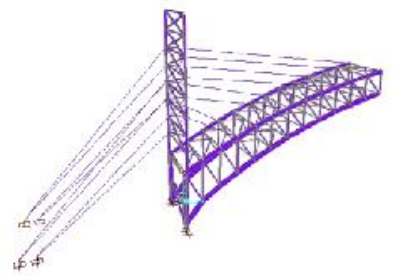

Gambar 39. Stage 4 Balanced Cantilever

Stage 5

Panjang tarikan main span $=15 \lambda=15 \times 5 \mathrm{~m}=75$ meter dengan panjang tarikan side span $=46$ meter. (gambar 40)

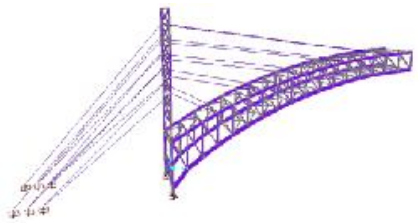

Gambar 40. Stage 5 Balanced Cantilever

\section{Stage 6}

Panjang tarikan main span $=18 \lambda=18 \times 5 \mathrm{~m}=90$ meter dengan panjang tarikan side span $=46$ meter. $($ gambar 41$)$

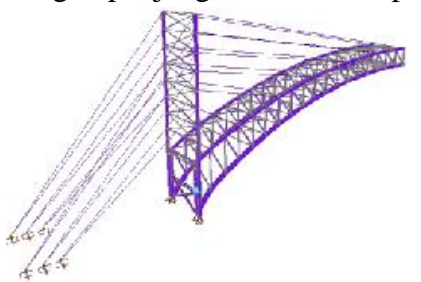

\section{Gambar 41. Stage 5 balanced cantilever}

Kontrol kapasitas kabel ditinjau dari kondisi maksimal yaitu pada stage 6. (tabel 10)

Tabel 10. Gaya tarikan kabel stage 6

\begin{tabular}{cccc}
\hline Elemen & $\begin{array}{c}\text { Gaya Tarikan } \\
\text { Kabel }(\mathrm{kN})\end{array}$ & $\begin{array}{c}\text { Min. Break } \\
\text { Load }(\mathrm{kN})\end{array}$ & Keterangan \\
\hline Main Span & 2172.304 & 5279 & OK \\
Side Span & 1876.541 & 5279 & OK \\
\hline
\end{tabular}

\section{Simpulan}

Dari hasil modifikasi desain duplikasi Jembatan Sembayat dengan struktur busur rangka baja maka diperoleh data - data perencanaan sebagai berikut:

1. Dimensi jembatan dengan panjang bentang 180 meter, lebar jalan (4/2 UD) 12 meter dengan 2 lajur ke arah 
Tuban dan 2 lajur ke arah Gresik ditambah 1,5 meter lebar trotoar di masing-masing sisi jembatan,

2. Untuk dimensi busur sendiri, memiliki tinggi fokus busur 35 meter dan tinggi penampang 6 meter,

3. Tebal plat lantai jembatan $25 \mathrm{~cm}$ dengan mutu beton fc' $35 \mathrm{MPa}$,

4. Mutu baja profil yang digunakan adalah BJ 55,

5. Profil gelagar memanjang WF 488 x $300 \times 18 \times 11$, sedangkan untuk profil gelagar melintang WF $900 \mathrm{x}$ 300 x 28 x 16 dengan ikatan angin pada lantai kendaraan berupa box $250 \times 250 \times 18$,

6. Cable rod yang digunakan adalah tipe kabel M520 carbon steel dengan ukuran M105 (diameter $102 \mathrm{~mm}$ ),

7. Elemen busur atas menggunakan box $900 \times 700 \times 50$, sedangkan elemen busur bawah menggunakan box $1100 \times 900 \times 50$,

8. Kolom portal akhir menggunakan $700 \times 700 \times 25$, sedangkan balok portal akhir menggunakan box $350 \mathrm{x}$ $350 \times 12$,

9. Perletakan menggunakan jembatan menggunakan sistem perletakan rol dan sendi,

10. Abutment jembatan direncanakan dengan tinggi dinding 6 meter dan lebar 15 meter. Untuk lebar pile cap pada abutment direncanakan 17,2 meter dengan tebal 2 meter. Mutu beton yang digunakan adalah f'c $30 \mathrm{MPa}$.

11. Pilar jembatan direncanakan dengan tinggi kolom 6 meter dan lebar 15 meter. Untuk lebar pile cap pada pilar direncanakan 17,2 meter dengan tebal 1,5 meter. Mutu beton yang digunakan adalah f'c $30 \mathrm{MPa}$.

12. Pondasi pada struktur abutment dan pilar menggunakan tiang pancang beton (spun pile) dengan diameter $60 \mathrm{~cm}$.

13. Metode pelaksanan struktur bangunan atas direncanakan menggunakan metode balanced cantilever dengan menggunakan tension cable yang dihubungkan ke temporary tower.

\section{Daftar Pustaka}

[1] I. Subarkah, Jembatan Baja. Bandung: Idea Dharma, 1979.

[2] A. N. Refani, D. P. Dibiantara, M. Suluch, and A. F. Muqoddam, "Studi Alternatif Bentuk Rangka Jembatan Canai Dingin Untuk Pejalan Kaki Bentang Kecil Terhadap Rasio Berat dan Lendutan," J. Apl. Tek. Sipil, vol. 15, no. 1, pp. 25-30, Nov. 2017.

[3] Soemargono dari Naskah Ir.H.J.Struyk dan Prof.Ir.K.H.C.W.Van Der Veen, Djembatan. Jakarta: Buku Tehnik H.Stam, 1953.

[4] BSN (Badan Standarisasi Nasional), RSNI T-03-2005 Perencanaan Struktur Baja Untuk Jembatan. Jakarta: BSN, 2005.

[5] BSN (Badan Standarisasi Nasional), RSNI T-12-2004
Perencanaan struktur beton untuk jembatan. Jakarta: BSN, 2004.

[6] BSN (Badan Standarisasi Nasional), SNI 1725:2016 Pembebanan untuk jembatan. Jakarta: BSN, 2016.

[7] BSN (Badan Standarisasi Nasional), SNI 2833:2016 Perancangan jembatan terhadap beban gempa. Jakarta: BSN, 2016.

[8] R. Prasmoro, R. Prasmoro, H. S. Masiran, and E. Wahyuni, "Modifikasi Jembatan Sembayat Baru II Menggunakan Sistem Jembatan Busur Rangka Baja," J. Tek. ITS, vol. 6, no. 1, pp. 13-18, Mar. 2017.

[9] AISC (American Institute Of Steel Construction), Specification for Structural Steel Buildings. Chicago: AISC, 2016. 